\title{
The family infighting continues: dualling Src family kinases now linked to activating IgG receptor signaling and anaphylaxis
}

\section{Andrew W. B. Craig* \\ Department of Biomedical and Molecular Sciences, Queen's University, Kingston, ON, Canada \\ *Correspondence: andrew.craig@queensu.ca}

Edited by:

Janos G. Filep, University of Montreal, Canada

\section{A commentary on}

The Fyn-STAT5 pathway: a new Frontier in IgE- and IgG-mediated mast cell signaling. by Pullen, N. A., Falanga, Y. T., Morales, J. K., and Ryan, J. J. (2012). Front. Immun. 3:117. doi: 10.3389/fimmu.2012.00117

Since the dawn of human civilization, stories of fierce family rivalries have captured our interest. While the outcomes are less severe than the classic tales of family feuds during Tudor reign in England, there is increasing evidence for family infighting within the Src family protein-tyrosine kinases (SFKs) in immunity and allergic diseases. In mast cells activated via IgE receptor (FcERI) aggregation, signaling is initiated by SFKs that phosphorylate immunoreceptor tyrosine-based activating motifs (ITAMs) to recruit downstream effectors that promote degranulation, lipid mediator, and cytokine/chemokine production. Although several SFKs participate, Lyn and Fyn are the key protagonists. Lyn initiates FcERI signaling by phosphorylating ITAMs, leading to recruitment of Fyn and Syk kinases that promote mediator production and release (Metcalfe et al., 2009). However, Lyn also puts the brakes on mast cell activation by phosphorylating immunoreceptor tyrosine-based inhibitory motifs (ITIMs) that recruit protein and lipid phosphatases. Lyn also promotes membrane recruitment and activation of C-terminal Src kinase (Csk) that phosphorylates SFKs to promote their return to an autoinhibited state (Gilfillan and Rivera, 2009).

In this issue of Frontiers in Inflammation, Pullen et al. (2012) review important advances in our understanding of how activating, or ITAM-bearing IgG receptors signal via SFKs in mast cells. Not surprisingly, there are some similarities with FceRI signaling mechanisms, and the Lyn vs. Fyn battle is maintained in these pathways. This review is also timely considering the emergence of activating IgG receptors as key inducers of anaphylaxis. Ryan and co-workers recently showed that Lyn suppresses IgG-mediated systemic anaphylaxis in mice (Falanga et al., 2012). In addition, seminal studies from the Bruhns lab implicate activating $\operatorname{IgG}$ receptor signaling in neutrophils, as a key source of platelet-activating factor (PAF) that triggers systemic anaphylaxis and airway inflammation (Jonsson et al., 2011, 2012). These and other studies of IgG signaling in immune cells will undoubtedly spur new research and discoveries of new therapeutic targets and treatments for allergic diseases.

\section{REFERENCES}

Falanga, Y. T., Chaimowitz, N. S., Charles, N., Finkelman, F. D., Pullen, N.A., Barbour, S., Dholaria, K., Faber, T.
Kolawole, M., Huang, B., Odom, S., Rivera, J., Carlyon, J., Conrad, D. H., Spiegel, S., Oskeritzian, C. A., and Ryan, J. J. (2012). Lyn but not Fyn kinase controls IgG-mediated systemic anaphylaxis. J. Immunol. 188 , $4360-4368$.

Gilfillan, A. M., and Rivera, J. (2009). The tyrosine kinase network regulating mast cell activation. Immunol. Rev. $228,149-169$

Jonsson, F., Mancardi, D. A., Kita, Y., Karasuyama, H., Iannascoli, B., Van Rooijen, N., Shimizu, T., Daeron, M., and Bruhns, P. (2011). Mouse and human neutrophils induce anaphylaxis. J. Clin. Invest. 121, 1484-1496. Jonsson, F., Mancardi, D. A., Zhao, W., Kita, Y., Iannascoli, B., Khun, H., Van Rooijen, N., Shimizu, T., Schwartz, L. B., Daeron, M., and Bruhns, P. (2012). Human FcgammaRIIA induces anaphylactic and allergic reactions. Blood 119, 2533-2544.

Metcalfe, D. D., Peavy, R. D., and Gilfillan, A. M. (2009). Mechanisms of mast cell signaling in anaphylaxis. J. Allergy Clin. Immunol. 124, 639-646.

Pullen, N. A., Falanga, Y. T., Morales, J. K., and Ryan, J. J. (2012). The Fyn-STAT5 pathway: a new Frontier in IgE- and IgG-mediated mast cell signaling. Front. Immun. 3:117. doi: 10.3389/fimmu.2012.00117

Received: 11 May 2012; accepted: 13 May 2012; published online: 06 June 2012.

Citation: Craig AWB (2012) The family infighting continues: dualling Srcfamily kinases now linked to activating $I g G$ receptor signaling and anaphylaxis. Front. Immun. 3:137. doi: 10.3389/fimmu.2012.00137

This article was submitted to Frontiers in Inflammation, a specialty of Frontiers in Immunology.

Copyright $\odot 2012$ Craig. This is an open-access article distributed under the terms of the Creative Commons Attribution Non Commercial License, which permits non-commercial use, distribution, and reproduction in other forums, provided the original authors and source are credited. 